\title{
Modeling the Effects of Temperature and Photosynthetic Daily Light Integral on Growth and Flowering of Salvia splendens and Tagetes patula
}

\author{
Lee Ann Moccaldi ${ }^{1}$ and Erik S. Runkle ${ }^{2,3}$ \\ Department of Horticulture, Michigan State University, A240-C PSSB, East Lansing, MI 48824
}

\begin{abstract}
AdDitional INDEX words. bedding plants, light intensity, marigold, scheduling
Abstract. Photosynthetic daily light integral (DLI) and temperature are two environmental factors that profoundly influence plant growth and development. Two common ornamental annual crops, salvia (Salvia splendens F. Sello ex Roem \& Schult.) and marigold (Tagetes patula L.), were grown in glass greenhouses under a mean DLI of 5 to $25 \mathrm{~mol} \cdot \mathrm{m}^{-2} \cdot \mathrm{d}^{-1}$ at temperatures from 14 to $27^{\circ} \mathrm{C}$. Growth (e.g., plant dry weight at flowering) and flowering characteristics (e.g., time to flowering and flower number) were modeled in response to the mean daily temperature and DLI by using multiple regression analysis. The rate of progress to flowering of salvia and marigold was primarily influenced by the mean air temperature. For example, time from seedling transplant to flowering of salvia decreased from 42 days to 24 days as temperature increased from 15 to $25^{\circ} \mathrm{C}$, with a mean DLI of $10 \mathrm{~mol} \cdot \mathrm{m}^{-2} \cdot \mathrm{d}^{-1}$. Flower number and plant dry weight on the date of first flowering generally decreased with increasing temperature and decreasing DLI in both species. For example, marigold plants grown at $15{ }^{\circ} \mathrm{C}$ and a mean DLI of $25 \mathrm{~mol} \cdot \mathrm{m}^{-2} \cdot \mathrm{d}^{-1}$ were 2.45 times greater in dry weight, had 2.12 more flowers, and had $49 \%$ larger flowers at flowering compared with plants grown at $25{ }^{\circ} \mathrm{C}$ and a mean DLI of $5 \mathrm{~mol} \cdot \mathrm{m}^{-2} \cdot \mathrm{d}^{-1}$. The models can be used to predict the impact of changing light and temperature conditions on plant quality and flowering of these two crops.
\end{abstract}

Commercial production of ornamental annuals is the largest contributor to the value of floriculture in the United States, with a reported wholesale value of $\$ 1.9$ billion in 2005 (U.S. Department of Agriculture, 2006). The majority of ornamental annual plants are produced in greenhouses from January through May for sales in spring and early summer. During this period, plants are exposed to a wide range of temperature and light conditions. In addition, greenhouse growers often produce multiple crops during this period, so the environmental conditions provided to an early spring crop are usually different from the conditions provided in the same location to a later crop.

Temperature is the most commonly manipulated environmental factor in greenhouse production. The growing temperature used by commercial growers depends on numerous factors, including time of year, greenhouse location, environmental control systems, fuel cost for heating, crop finish dates, desired plant quality and size, stage of development, and plant species. The rate of plant development is a function of temperature and usually increases linearly from above the species-specific base temperature until the optimum temperature (Roberts and Summerfield, 1987). In addition, temperature also influences plant quality parameters such as flower number and size, branching, and mass. For example, flower bud number and flower size of tickseed (Coreopsis grandiflora Hogg ex Sweet.), blanket flower (Gaillardia $\times$ grandiflora Van Houtte), and shasta daisy (Leucanthemum $\times$ superbum Bergman ex.

Received for publication 29 Sept. 2006. Accepted for publication 29 Jan. 2007. We gratefully acknowledge funding from growers providing support for Michigan State University floriculture research and the support from the Michigan Agricultural Exp. Sta.

${ }^{1}$ Former graduate student (Lee Ann Pramuk).

${ }^{2}$ Assistant Professor of Horticulture and Extension Specialist.

${ }^{3}$ Corresponding author. E-mail: runkleer@msu.edu.
J. Ingram) increased as mean daily temperature decreased from 27 to $15^{\circ} \mathrm{C}$ (Yuan et al., 1998).

Ornamental annuals are also exposed to a range of photosynthetic daily light integrals (DLIs), depending on the time of year, greenhouse location, light transmission to the crops, and supplemental lighting. For example, the mean outdoor DLI in Michigan is less than $15 \mathrm{~mol} \cdot \mathrm{m}^{-2} \cdot \mathrm{d}^{-1}$ in January and more than $50 \mathrm{~mol} \cdot \mathrm{m}^{-2} \cdot \mathrm{d}^{-1}$ in May (Korczynski et al., 2002). Assuming a typical greenhouse light transmission of 50\% (Hanan, 1998), ornamental annual crops can be grown under a mean DLI less than $8 \mathrm{~mol} \cdot \mathrm{m}^{-2} \cdot \mathrm{d}^{-1}$ to more than $25 \mathrm{~mol} \cdot \mathrm{m}^{-2} \cdot \mathrm{d}^{-1}$. Mean DLI can influence flower initiation and flowering parameters. For example, the number of days required for flower initiation of several cultivars of geranium (Pelargonium $\times$ domesticum L.H. Bailey) generally decreased as the DLI increased from 5 to $20 \mathrm{~mol} \cdot \mathrm{m}^{-2} \cdot \mathrm{d}^{-1}$ (Loehrlein and Craig, 2004). The interactive effects of DLI with temperature on plant growth and development have not been described for many floriculture crops.

Ornamental annuals propagated by seed are commonly produced in two distinct stages: the seedling stage and the finish stage. During the seedling stage, seeds are sown in plug trays that have small soil volumes and closely spaced growing cells. Seedlings are raised in plugs until plants have established a sufficient root system and adequate vegetative development, and are deemed ready for transplant. The finish stage begins on the date of transplant into larger containers and continues until plants are marketed. We performed experiments with two annual crops, marigold and salvia, to quantify how temperature and DLI influence growth and development during the finish stage. Marigold and salvia were selected for study because they are among the most popular species produced by the greenhouse industry in the United States (U.S. Department of Agriculture, 2006). Plants were grown at a mean daily temperature of 14 to $27^{\circ} \mathrm{C}$ with a mean DLI of 5 to $25 \mathrm{~mol} \cdot \mathrm{m}^{-2} \cdot \mathrm{d}^{-1}$, which represent the range of conditions for most commercial greenhouse 
companies that produce ornamental annuals. Plant models were then developed to predict the effect of changing temperature or DLI on growth and development of these two crops.

\section{Materials and Methods}

Seedling Plug Culture. Seeds of salvia 'Vista Red' and marigold 'Bonanza Yellow' were sown in 288-cell (5-mL) plug trays on $25 \mathrm{Jan}$. and 2 Apr. at a wholesale plug producer (Raker's Acres, Litchfield, Mich.). The germinated seeds were received at Michigan State University on 29 Jan. and 8 Apr. so that the DLI during the seedling stage could be controlled. The 288-cell trays were placed in a growth chamber set at $23{ }^{\circ} \mathrm{C}$ under $150 \mu \mathrm{mol} \cdot \mathrm{m}^{-2} \cdot \mathrm{s}^{-1}$ provided by cool-white fluorescent (VHOF96T12; Philips, Bloomfield, N.J.) and incandescent lamps with a 16-h photoperiod. A vapor pressure deficit of $0.7 \mathrm{kPa}$ was maintained. Plugs were top irrigated with acidified well water supplemented with a water-soluble fertilizer to provide micronutrients: $40 \mathrm{mg} \cdot \mathrm{L}^{-1} \mathrm{~N}, 4 \mathrm{mg} \cdot \mathrm{L}^{-1} \mathrm{P}, 40 \mathrm{mg} \cdot \mathrm{L}^{-1}$ $\mathrm{K}$, and $5 \mathrm{mg} \cdot \mathrm{L}^{-1} \mathrm{Ca}$ (Pramuk and Runkle, 2005a). Seedlings were grown until deemed ready for transplant, which was 19 and $26 \mathrm{~d}$ from sowing for marigold and salvia respectively.

Greenhouse TEMPERATURE AND DLI TREATMENTS. For each species and experiment, 150 seedlings were removed from the growth chamber and transplanted into $10-\mathrm{cm}$-diameter pots (470 $\mathrm{mL}$ ) containing $70 \%$ peatmoss, $21 \%$ perlite, and $9 \%$ vermiculite (Suremix; Michigan Grower Products, Galesburg, Mich.). Thirty plants of each species were placed (with $\approx 15-\mathrm{cm}$ center spacing) into five similar glass greenhouse compartments set at constant air temperatures of 14, 17, 20, 23, and $26^{\circ} \mathrm{C}$. In each greenhouse compartment, the water vapor pressure deficit was calculated using a dry and wet bulb temperature and was maintained between 0.7 and $1.0 \mathrm{kPa}$ by steam injection into the air. In the center of each greenhouse section, air temperature was measured by a type E thermocouple (TT-E-40; Omega Engineering, Stamford, Conn.) placed in an aspirated tube. Thermocouples were connected to a CR10 data logger (Campbell Scientific, Logan, Utah), and data were recorded every $10 \mathrm{~s}$.

Three DLI treatments were provided to plants at each of the five temperature treatments, with 10 plants under each DLI and temperature combination. The DLI treatments were delivered using a combination of shade cloth and different light intensities from high-pressure sodium (HPS) lamps from 0600 to $2200 \mathrm{HR}$ to achieve a 16 -h photoperiod. A low DLI was provided using ambient light with $50 \%$ shade cloth (OLS 50; Ludvig Svensson, Charlotte, N.C.) and supplemental HPS lighting that delivered a photosynthetic photon flux $(P P F)$ of $35 \mu \mathrm{mol} \cdot \mathrm{m}^{-2} \cdot \mathrm{s}^{-1}$ at plant level. Plants under the moderate and high DLI treatments were grown under ambient light without shade cloth and with supplemental HPS lighting that provided a $P P F$ of 75 or $170 \mu \mathrm{mol} \cdot \mathrm{m}^{-2} \cdot \mathrm{s}^{-1}$ respectively. Line quantum sensors containing 10 photodiodes (Apogee Instruments, Logan, Utah) were placed directly above plants under the three lighting treatments in three greenhouse compartments (nine sensors total) to measure $P P F$. Sensors were connected to the same CR10 data logger and data were recorded every $10 \mathrm{~s}$.

Plant Culture and data collection. Plants were top irrigated as necessary with acidified well water [as described by Pramuk and Runkle (2005a)] supplemented with a watersoluble fertilizer containing $125 \mathrm{mg} \cdot \mathrm{L}^{-1} \mathrm{~N}, 13 \mathrm{mg} \cdot \mathrm{L}^{-1} \mathrm{P}$, $125 \mathrm{mg} \cdot \mathrm{L}^{-1} \mathrm{~K}, 15 \mathrm{mg} \cdot \mathrm{L}^{-1} \mathrm{Ca}, 1 \mathrm{mg} \cdot \mathrm{L}^{-1} \mathrm{Fe}, 0.1 \mathrm{mg} \cdot \mathrm{L}^{-1} \mathrm{~B}$ and $\mathrm{Mo}$, and $0.5 \mathrm{mg} \cdot \mathrm{L}^{-1} \mathrm{Mn}, \mathrm{Zn}$, and $\mathrm{Cu}$ (MSU Special; GreenCare
Fertilizers, Kankakee, Ill.). Date of flowering was monitored daily and was recorded, and at flowering, the following were measured: plant height from soil level to the inflorescence apex, number of nodes on the primary shoot, total shoot dry weight, number of inflorescences (flower number), and diameter of the first open floret (salvia) or inflorescence (marigold). Marigold was considered in flower when all petals were fully reflexed; salvia was considered in flower when the first floret opened.

DAta AnAlysis. Data were analyzed using the calculated mean daily air temperature and DLI for each plant from transplant to the date of flowering. Flowering data were converted to rates (flowering rate) by taking the reciprocal of days to flowering (1/d to flowering). Multiple regression analysis was performed using SAS (SAS Institute, Cary, N.C.) response surface regression (RSREG procedure) to determine the effect of DLI in combination with air temperature. Similar studies with temperature and DLI have used similar forms of analysis (Adams et al., 1997; Carew et al., 2003; Pramuk and Runkle, 2005a). If the contribution of individual terms to the model was nonsignificant at $P>0.05$, the terms were removed and the regression (REG procedure) was used to determine the model coefficients. Equations were then used to generate predictive models based on $\approx 300$ observations (both experimental replications) for each species. The models in Fig. 1 and Fig. 2 are in the form of

$$
\mathrm{y}=\mathrm{y}_{0}+\mathrm{aT}+\mathrm{bT}^{2}+\mathrm{cDLI}+\mathrm{dDLI}^{2}+\mathrm{eT} \times \mathrm{DLI}
$$

where $y$ equals the plant parameter, $\mathrm{y}_{0}$ is the $\mathrm{y}$-axis intercept, $\mathrm{T}$ is temperature (measured in degrees Celsius), DLI is the mean daily light integral (measured in moles per square meter per day), and a, b, c, d, and e are species-specific constants presented in Table 1. Response minimums (e.g., minimum plant height) and maximums (e.g., maximum plant height) were the calculated points of inflection of the response surfaces and were rounded to the nearest $1{ }^{\circ} \mathrm{C}$. Axes for Figs. $1 \mathrm{C}, 1 \mathrm{D}, 3 \mathrm{C}$, and $3 \mathrm{D}$ were reversed to improve clarity of the data; otherwise, response surfaces would have sloped away, making interpretations more difficult. Base temperature, the temperature at which plant development stops, was estimated under 5 and $15 \mathrm{~mol} \cdot \mathrm{m}^{-2} \cdot \mathrm{d}^{-1}$ by inputting the DLI into the flowering rate equation and setting the equation equal to zero. The DLI parameter was included in the base temperature calculations because plants grown at a high irradiance are usually warmer than plants grown at a lower irradiance at the same air temperature (Pietsch et al., 1995; Shimizu et al., 2004). Therefore, we used air temperature and DLI collectively to estimate the plant temperature at which the flowering rate was zero (base temperature).

\section{Results}

SALVIA. The flowering rate was primarily controlled by the mean air temperature, but there was an interaction with mean DLI (Table 1). For example, increasing the temperature from 15 to $25^{\circ} \mathrm{C}$ under a mean DLI of $10 \mathrm{~mol} \cdot \mathrm{m}^{-2} \cdot \mathrm{d}^{-1}$ decreased flowering time from $42 \mathrm{~d}$ to $24 \mathrm{~d}$; under a mean DLI of $20 \mathrm{~mol} \cdot \mathrm{m}^{-2} \cdot \mathrm{d}^{-1}$, flowering time decreased from $37 \mathrm{~d}$ to $21 \mathrm{~d}$ (Fig. 1). Flowering rate continued to increase with temperature, and thus an optimum temperature for maximal development was not determined. The flowering time model accurately described the data set of salvia within $\pm 5 \mathrm{~d}$ for $90 \%$ of the 

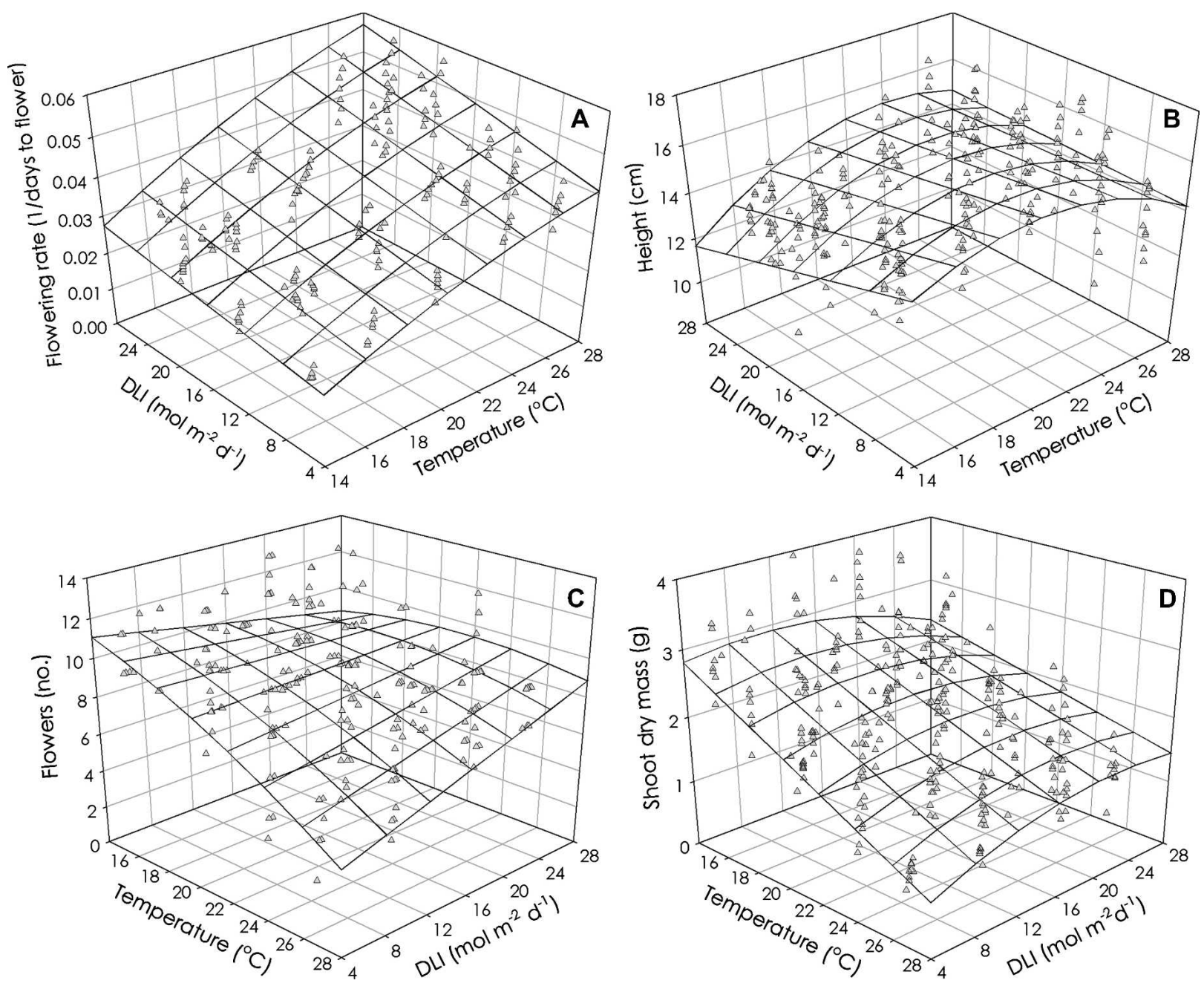

Fig. 1. (A-D) Temperature and daily light integral (DLI) effects on salvia flowering rate (A; 1/d to flowering) and plant height (B), flower bud number (C), and shoot dry weight at flowering (D). The coefficients for the models are presented in Table 1. Symbols represent measured data, and response surfaces represent model predictions. Axes for $\mathbf{C}$ and $\mathbf{D}$ were reversed to improve clarity of data.

actual data (Fig. 2). The calculated base temperature under a mean DLI of 5 or $15 \mathrm{~mol} \cdot \mathrm{m}^{-2} \cdot \mathrm{d}^{-1}$ was 7.3 or $6.8^{\circ} \mathrm{C}$ respectively.

Temperature and DLI did not have a significant effect on node number at flowering, which averaged 8.5 and 7.0 in the January and April experiments respectively (data not presented). Plant height at flowering increased with temperature until a maximum at $20^{\circ} \mathrm{C}$ under $5 \mathrm{~mol} \cdot \mathrm{m}^{-2} \cdot \mathrm{d}^{-1}(16.2 \mathrm{~cm})$ and at $24{ }^{\circ} \mathrm{C}$ under $25 \mathrm{~mol} \cdot \mathrm{m}^{-2} \cdot \mathrm{d}^{-1}(15.2 \mathrm{~cm})$. Plant height decreased with increasing DLI at temperatures ranging from 14 to $24{ }^{\circ} \mathrm{C}$. Plant height was highly variable, especially at temperatures more than $25^{\circ} \mathrm{C}$, and therefore the $r^{2}$ value was relatively low. Flower number generally decreased with increasing temperature, but was between 9 and 11 when the mean daily temperature was $\leq 20^{\circ} \mathrm{C}$. Salvia had the fewest flowers when grown at the warmest temperatures and lowest mean DLI (e.g., plants averaged six flowers when grown at $26{ }^{\circ} \mathrm{C}$ and a mean DLI of $\left.6 \mathrm{~mol} \cdot \mathrm{m}^{-2} \cdot \mathrm{d}^{-1}\right)$. Flower size was not significantly influenced by growing temperature or DLI (data not presented). Shoot dry weight at first flowering was primarily influenced by temperature and increased as temperature decreased, especially when the DLI was low. For example, mean dry weight of salvia was $42 \%$ greater when grown at $18{ }^{\circ} \mathrm{C}$ than at $24{ }^{\circ} \mathrm{C}$ at a mean DLI of $10 \mathrm{~mol} \cdot \mathrm{m}^{-2} \cdot \mathrm{d}^{-1}$.
MARIGOLD. Flowering rate increased as DLI and temperature increased, and a temperature for maximal development was not determined (Table 1; Fig. 3). The flowering time model accurately described the data set within $\pm 5 \mathrm{~d}$ for $91 \%$ of the actual data (Fig. 2). Plants grown under a mean DLI of $10 \mathrm{~mol} \cdot \mathrm{m}^{-2} \cdot \mathrm{d}^{-1}$ flowered in $36 \mathrm{~d}$ at $15{ }^{\circ} \mathrm{C}$ and in $23 \mathrm{~d}$ at $25^{\circ} \mathrm{C}$. Increasing the DLI to $20 \mathrm{~mol} \cdot \mathrm{m}^{-2} \cdot \mathrm{d}^{-1}$ reduced flowering time by $6 \mathrm{~d}$ at $15{ }^{\circ} \mathrm{C}$ and $4 \mathrm{~d}$ at $25^{\circ} \mathrm{C}$. The calculated base temperature was $-2.9^{\circ} \mathrm{C}$, regardless of DLI. The number of nodes that developed before flowering was not influenced by temperature or mean DLI and averaged 5.4 (data not shown).

Mean plant height at flowering increased by $0.17 \mathrm{~cm}$ for every $1{ }^{\circ} \mathrm{C}$ increase in average daily temperature and by $0.07 \mathrm{~cm}$ for every $1 \mathrm{~mol} \cdot \mathrm{m}^{-2} \cdot \mathrm{d}^{-1}$ increase in the DLI. Flower number and flower diameter were greatest when DLI was high and the average temperature was low. Within the DLI range tested, an increase in DLI by $5 \mathrm{~mol} \cdot \mathrm{m}^{-2} \cdot \mathrm{d}^{-1}$ increased flower number by 1.3 and flower diameter by $0.16 \mathrm{~cm}$. Lowering the mean daily temperature by $5{ }^{\circ} \mathrm{C}$ increased flower number at first flowering by 3.7 and increased flower size by $0.65 \mathrm{~cm}$. Dry weight was greatest at the coolest temperatures and highest DLI, and decreased with increasing temperature. Plants grown at $15{ }^{\circ} \mathrm{C}$ and a DLI of $25 \mathrm{~mol} \cdot \mathrm{m}^{-2} \cdot \mathrm{d}^{-1}$ were 2.45 times greater in 


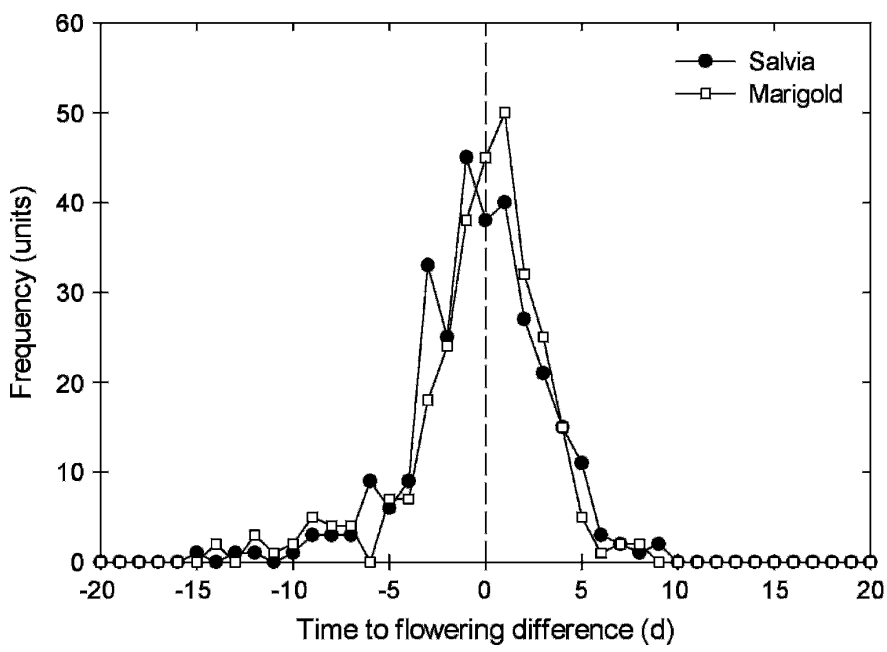

Fig. 2. Frequency of predicted minus actual days to flowering in salvia and marigold grown at different temperatures $\left(\approx 14\right.$ to $\left.27{ }^{\circ} \mathrm{C}\right)$ and daily light integrals $\left(\approx 5\right.$ to $\left.25 \mathrm{~mol} \cdot \mathrm{m}^{-2} \cdot \mathrm{d}^{-1}\right)$. The models used to predict flowering time are shown in Table 1 and are based on more than 290 observations for each species.

shoot dry weight, had 2.12 more flowers, and had 49\% larger flowers than plants grown at $25{ }^{\circ} \mathrm{C}$ and a mean DLI of $5 \mathrm{~mol} \cdot \mathrm{m}^{-2} \cdot \mathrm{d}^{-1}$.

\section{Discussion}

The flowering rate of salvia and marigold was primarily controlled by temperature within the experimental conditions provided. Similarly, mean DLI during the finish stage did not influence node number at flowering in celosia (Celosia argentea L. var. plumosa L.) and impatiens (Impatiens wallerana Hook.f.) (Pramuk and Runkle, 2005a). Faust et al. (2005) reported that increasing the DLI from 5 to $43 \mathrm{~mol} \cdot \mathrm{m}^{-2} \cdot \mathrm{d}^{-1}$ during the finish stage accelerated flowering (by $<5 \mathrm{~d}$ ) in Salvia coccinea L., but Tagetes erecta L. flowered at a similar time under a DLI of 19 or $43 \mathrm{~mol} \cdot \mathrm{m}^{-2} \cdot \mathrm{d}^{-1}$; node number at flowering was not reported. In contrast, an increase in DLI during the seedling stage accelerated subsequent flower initiation in the same salvia and marigold cultivars used in this study as well as in celosia and impatiens (Pramuk and Runkle, 2005b). This suggests that plants used in this study had at least partially initiated flowers during the seedling stage and before the onset of treatments, or that the promotive effects of a high DLI on flower initiation decrease with an increase in plant size or maturity.

Flowering rate of marigold and salvia continued to increase with mean daily temperature up to the warmest treatment provided $\left(27^{\circ} \mathrm{C}\right)$, and thus a maximum developmental rate was not identified for either species. In marigold, whole-plant net photosynthesis was greater in plants grown at $30{ }^{\circ} \mathrm{C}$ than at $20{ }^{\circ} \mathrm{C}$, which suggests the maximal developmental rate is achieved at more than $30{ }^{\circ} \mathrm{C}$ (van Iersel and Seymour, 2003). Temperatures for maximal rates of development have been reported for several other bedding plant species, including pansy (Viola $\times$ wittrockiana Gams.; $22{ }^{\circ} \mathrm{C}$ ), dahlia (Dahlia pinnata Cav.; $24{ }^{\circ} \mathrm{C}$ ), petunia (Petunia $\times$ hybrida Vilm.-Andr.; $\left.25^{\circ} \mathrm{C}\right)$ ], celosia $\left(25^{\circ} \mathrm{C}\right)$, impatiens $\left(26^{\circ} \mathrm{C}\right)$, and vinca (Catharanthus roseus L., $35^{\circ} \mathrm{C}$ ) (Adams et al., 1997; Brøndum and Heins, 1993; Kaczperski et al., 1991; Pietsch et al., 1995; Pramuk and Runkle, 2005a).

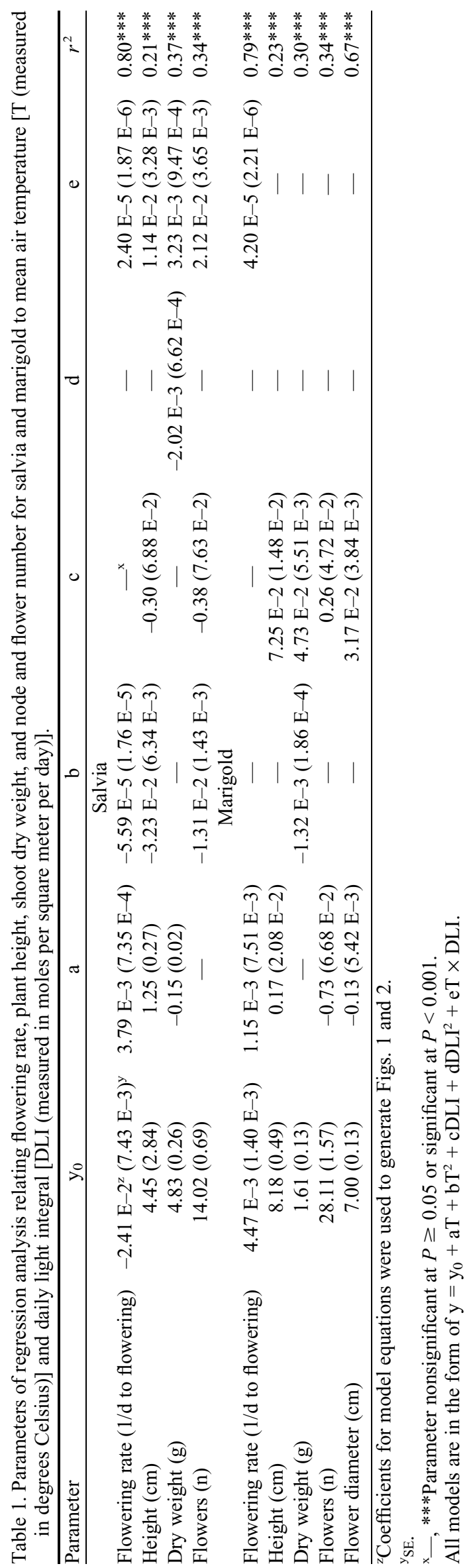



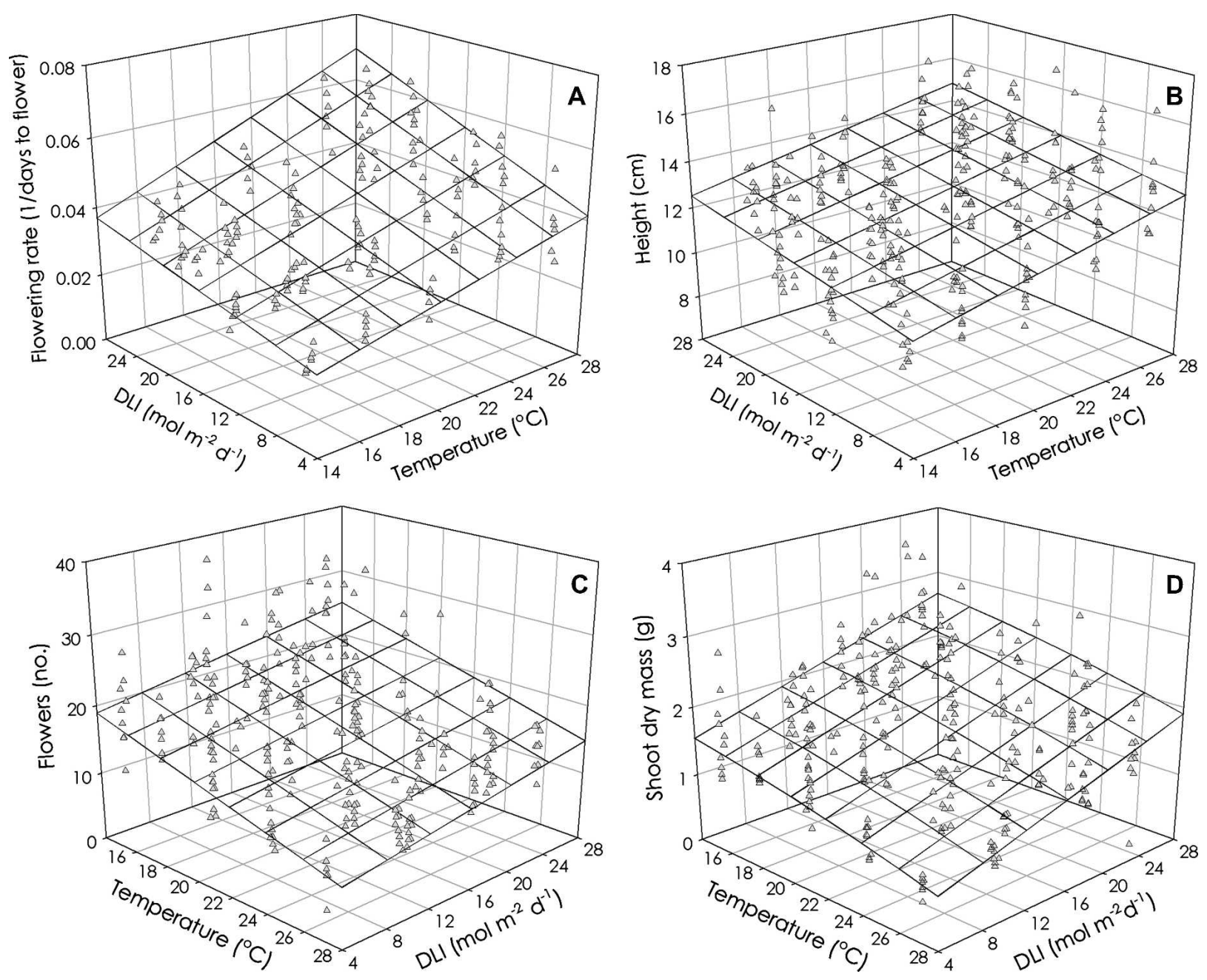

Fig. 3. (A-D) Temperature and daily light integral (DLI) effects on marigold flowering rate (A; 1 /days to flower) and flower diameter (B), flower bud number (C), and shoot dry weight at flowering (D). The coefficients for the models are presented in Table 1. Symbols represent measured data, and response surfaces represent model predictions. Axes for $\mathbf{C}$ and $\mathbf{D}$ were reversed to improve clarity of data.

The base temperature of a plant is usually identified by extrapolating the rate of development at temperatures below the data set until the rate reaches zero, and assumes linearity. The base temperatures calculated for marigold and salvia were based on the effect of air temperature and DLI on plant temperature, although DLI had little or no effect on the estimates for marigold $\left(\approx-3^{\circ} \mathrm{C}\right)$ and salvia $\left(\approx 7^{\circ} \mathrm{C}\right)$. In contrast, the estimated base temperature of celosia and marigold decreased by $1.5^{\circ} \mathrm{C}$ and $3.2{ }^{\circ} \mathrm{C}$ respectively, as DLI increased from 5 to $15 \mathrm{~mol} \cdot \mathrm{m}^{-2} \cdot \mathrm{d}^{-1}$ (Pramuk and Runkle, 2005a). The base temperature has been calculated for other herbaceous ornamental plants without consideration of DLI, including shasta daisy $\left(-3.4{ }^{\circ} \mathrm{C}\right)$, gaillardia $\left(3.3^{\circ} \mathrm{C}\right)$, dahlia $\left(5.5^{\circ} \mathrm{C}\right)$, and tickseed $\left(6.8^{\circ} \mathrm{C}\right)$ (Brøndum and Heins, 1993; Yuan et al., 1998).

Although the flowering rate increased with temperature in both species, plant quality parameters decreased, especially when the DLI was low. As daily temperature increased from 15 to $25^{\circ} \mathrm{C}$, flower number decreased from 10.3 to 7.0 in salvia and from 19.7 to 12.4 in marigold when the mean DLI was $10 \mathrm{~mol} \cdot \mathrm{m}^{-2} \cdot \mathrm{d}^{-1}$. In addition, flower size of marigold decreased by $24 \%$. Under the same DLI, models predicted the same $10{ }^{\circ} \mathrm{C}$ increase in forcing temperature to decrease flower number of celosia by $18 \%$ and impatiens by $58 \%$ (Pramuk and Runkle, 2005a). In pansy, flower size decreased by $26 \%$ or $37 \%$ as temperature increased from 18 to $24{ }^{\circ} \mathrm{C}$ under a mean DLI of $15.6 \mathrm{~mol} \cdot \mathrm{m}^{-2} \cdot \mathrm{d}^{-1}$ or $4.1 \mathrm{~mol} \cdot \mathrm{m}^{-2} \cdot \mathrm{d}^{-1}$ respectively (Niu et al., 2000). Similarly, flower diameter of dahlia decreased by $1.4 \mathrm{~mm} \cdot{ }^{\circ} \mathrm{C}^{-1}$ as temperature increased from 11 to $30{ }^{\circ} \mathrm{C}$ (Brøndum and Heins, 1993). The effects of forcing temperature on flower number and size have also been described in several herbaceous perennials. For example, an increase in forcing temperature from 16 to $26{ }^{\circ} \mathrm{C}$ decreased flower number of tickseed, rudbeckia (Rudbeckia fulgida Ait. 'Goldsturm'), and shasta daisy by $80 \%, 75 \%$, and $55 \%$ respectively (Yuan et al., 1998). In addition, a decrease in forcing temperature from 26 to $14{ }^{\circ} \mathrm{C}$ increased flower size of campanula ( Campanula carpatica Jacq.) and Campanula L. 'Birch Hybrid' by $35 \%$ (Niu et al., 2001).

The increase in flower number of salvia (when temperature was $\geq 19{ }^{\circ} \mathrm{C}$ ) and flower number and size of marigold from an increasing DLI is consistent with data for several other greenhouse crops, including wax begonia (Begonia Xsemperflorens-cultorum L.), campanula, celosia, hibiscus (Hibiscus radiatus Cav.), impatiens, marigold, pansy, petunia, vinca (Catharanthus roseus L.), and zinnia (Zinnia elegans L.) (Faust et al., 2005; Niu et al., 2000, 2001; Pramuk and Runkle, 
2005a; Warner and Erwin, 2003). However, few studies have quantified the interactive effects of temperature and DLI on flowering characteristics. In Primula vulgaris Huds., the DLI that elicited the most rapid flower initiation decreased (to $11 \mathrm{~mol} \cdot \mathrm{m}^{-2} \cdot \mathrm{d}^{-1}$ ) as temperature increased to $13{ }^{\circ} \mathrm{C}$, then increased with temperature (Karlsson, 2002). Our data indicate that at a warmer growing temperature, a higher DLI is required to produce a plant of comparable quality to plants grown at a cooler temperature. For example, to produce a crop of marigold with $\geq 15$ flower buds, the model indicates that plants could be grown at a mean daily temperature of less than $20{ }^{\circ} \mathrm{C}$ when the DLI is $5 \mathrm{~mol} \cdot \mathrm{m}^{-2} \cdot \mathrm{d}^{-1}$, but at $25^{\circ} \mathrm{C}$, a mean DLI $\geq 20 \mathrm{~mol} \cdot \mathrm{m}^{-2} \cdot \mathrm{d}^{-1}$ is required.

Time from transplant to flower increased with decreasing temperature, and thus plants grown at the lower temperatures were older and had a greater accumulated DLI before flowering. Dry weight of marigold increased as DLI increased from 5 to $25 \mathrm{~mol} \cdot \mathrm{m}^{-2} \cdot \mathrm{d}^{-1}$, but the effect of DLI on salvia depended on temperature. Salvia grown at $26^{\circ} \mathrm{C}$ had the greatest dry weight under a DLI of $22 \mathrm{~mol} \cdot \mathrm{m}^{-2} \cdot \mathrm{d}^{-1}$, whereas dry weight was greatest at $16{ }^{\circ} \mathrm{C}$ when the DLI was $13 \mathrm{~mol} \cdot \mathrm{m}^{-2} \cdot \mathrm{d}^{-1}$. In celosia and impatiens, dry weight at flowering increased as DLI increased from 5 to $25 \mathrm{~mol} \cdot \mathrm{m}^{-2} \cdot \mathrm{d}^{-1}$, regardless of temperature (Pramuk and Runkle, 2005a). Faust et al. (2005) reported increases in dry weight with increasing DLI for several bedding plants grown outdoors at a mean daily temperature of $\approx 23{ }^{\circ} \mathrm{C}$. However, shoot dry weight of the shade-tolerant wax begonia and impatiens did not increase when the DLI increased from 19 to $43 \mathrm{~mol} \cdot \mathrm{m}^{-2} \cdot \mathrm{d}^{-1}$. Nemali and van Iersel (2004) reported that dry weight of wax begonia increased, but at a decreasing rate as DLI increased from 5.3 to $19.4 \mathrm{~mol} \cdot \mathrm{m}^{-2} \cdot \mathrm{d}^{-1}$.

The models generated can be used to predict the effects of temperature and DLI on growth and flowering of marigold and salvia in commercial settings. For example, a salvia crop grown at $20^{\circ} \mathrm{C}$ in Michigan and Florida in March could receive a mean DLI of 12 and $20 \mathrm{~mol} \cdot \mathrm{m}^{-2} \cdot \mathrm{d}^{-1}$ respectively, assuming $50 \%$ greenhouse light transmission (Korczynski et al., 2002). The models predict that salvia would take about $3 \mathrm{~d}$ longer to flower in Michigan, but dry weight and flower number would be essentially the same in both locations. In the same scenario, marigolds grown in Florida would flower $4 \mathrm{~d}$ earlier, have 5\% larger flowers, $12 \%$ more flower buds, and $23 \%$ greater dry weight compared with a crop grown under the lower DLI in Michigan that time of year. In addition, the data illustrate that plants of similar quality can be grown at a low mean daily temperature and DLI as at a high temperature and high DLI. For example, the flower number model for marigold predicts 17.7 buds per plant if grown at $17^{\circ} \mathrm{C}$ and a DLI of $8 \mathrm{~mol} \cdot \mathrm{m}^{-2} \cdot \mathrm{d}^{-1}$ or at $23{ }^{\circ} \mathrm{C}$ and a DLI of $25 \mathrm{~mol} \cdot \mathrm{m}^{-2} \cdot \mathrm{d}^{-1}$. However, marigold grown at $17^{\circ} \mathrm{C}$ would take $15 \mathrm{~d}$ longer to flower than at $23^{\circ} \mathrm{C}$. The models were developed with long-day conditions, and for photoperiodic salvia cultivars, the model may be less predictable if plants are grown under short days. Additional studies are merited to determine the effects of temperature and DLI on growth and development of other economically important greenhouse crops.

\section{Literature Cited}

Adams, S.R., S. Pearson, and P. Hadley. 1997. The effects of temperature, photoperiod and light integral on the time to flowering of pansy cv. Universal Violet (Viola $\times$ wittrockiana Gams.). Ann. Bot. (Lond.) 80:107-112.
Brøndum, J.J. and R.D. Heins. 1993. Modeling temperature and photoperiod effects on growth and development of dahlia. J. Amer. Soc. Hort. Sci. 118:36-42.

Carew, J.G., K. Mahood, J. Darby, P. Hadley, and N.H. Battey. 2003. The effect of temperature, photosynthetic photon flux density, and photoperiod on the vegetative growth and flowering of 'Autumn Bliss' raspberry. J. Amer. Soc. Hort. Sci. 128:291296.

Faust, J.E., V. Holcombe, N.C. Rajapakse, and D.R. Layne. 2005. The effect of daily light integral on bedding plant growth and flowering. HortScience 40:645-649.

Hanan, J. 1998. Greenhouses: Advanced technology for protected horticulture. CRC Press, Boca Raton, Fla.

Kaczperski, M.P., W.H. Carlson, and M.G. Karlsson. 1991. Growth and development of Petunia $\times$ hybrida as a function of temperature and irradiance. J. Amer. Soc. Hort. Sci. 116:232-237.

Karlsson, M.G. 2002. Flower formation in Primula vulgaris is affected by temperature, photoperiod, and daily light integral. Sci. Hort. 95:99-110.

Korczynski, P.M., J. Logan, and J.E. Faust. 2002. Mapping monthly distribution of daily light integrals across the contiguous United States. HortTechnology 12:12-16.

Loehrlein, M.M. and R. Craig. 2004. The effect of daily light integral on floral initiation of Pelargonium $\times$ domesticum L.H. Bailey. HortScience 39:529-532.

Nemali, K.W. and M.W. van Iersel. 2004. Light effects on wax begonia: Photosynthesis, growth respiration, maintenance respiration, and carbon use efficiency. J. Amer. Soc. Hort. Sci. 129:416424.

Niu, G., R.D. Heins, A.C. Cameron, and W.H. Carlson. 2000. Day and night temperatures, daily light integral, and $\mathrm{CO}_{2}$ enrichment affect growth and flower development of pansy (Viola $\times$ wittrockiana). J. Amer. Soc. Hort. Sci. 125:436-441.

Niu, G., R.D. Heins, A.C. Cameron, and W.H. Carlson. 2001. Temperature and daily light integral influence plant quality and flower development of Campanula carpatica 'Blue Clips', 'Deep Blue Clips', and Campanula 'Birch Hybrid'. HortScience 36:664668.

Pietsch, G.M., W.H. Carlson, R.D. Heins, and J.E. Faust. 1995. The effect of day and night temperature and irradiance on development of Catharanthus roseus (L.) 'Grape Cooler'. J. Amer. Soc. Hort. Sci. 120:877-881.

Pramuk, L.A. and E.S. Runkle. 2005a. Modeling growth and development of celosia and impatiens in response to temperature and photosynthetic daily light integral. J. Amer. Soc. Hort. Sci. 130:813-818.

Pramuk, L.A. and E.S. Runkle. 2005b. Photosynthetic daily light integral during the seedling stage influences subsequent growth and flowering of Celosia, Impatiens, Salvia, Tagetes, and Viola. HortScience 40:1336-1339.

Roberts, E.H. and R.J. Summerfield. 1987. Measurement and prediction of flowering in annual crops, p. 17-50. In: J.G. Atherton (ed.). Manipulation of flowering. Butterworths, London.

Shimizu, H., E.S. Runkle, and R.D. Heins. 2004. A steady-state model for prediction of poinsettia plant shoot-tip temperature. J. Amer. Soc. Hort. Sci. 129:303-312.

U.S. Department of Agriculture. 2006. Floriculture crops 2005 summary. U.S. Dept. Agr., Natl. Agr. Stat. Serv., Washington, D.C. van Iersel, M. and L. Seymour. 2003. Temperature effects on photosynthesis, growth respiration, and maintenance respiration of marigold. Acta Hort. 624:549-554.

Warner, R.M. and J.E. Erwin. 2003. Effect of photoperiod and daily light integral on flowering of five Hibiscus sp. Sci. Hort. 97:341-351.

Yuan, M., W.H. Carlson, R.D. Heins, and A.C. Cameron. 1998. Effect of forcing temperature on Coreopsis grandiflora, Gaillardia $\times$ grandiflora, Leucanthemum $\times$ superbum, and Rudbeckia fulgida. HortScience 33:663-667. 